\title{
APLIKASI SISTEM PAKAR UNTUK DIAGNOSA PENYAKIT MATA MENGGUNAKAN PHP DAN MYSQL
}

\author{
LUKMAN \\ Program Studi Informatika \\ Fakultas Teknik, dan Ilmu Komputer \\ Universitas Indraprasta PGRI \\ Jl. Nangka No. 58 C, Tanjung Barat, Jagakarsa, Jakarta Selatan 12530 \\ Email: Lkmnaja51@gmail.com
}

\begin{abstract}
Along with the development of technology, also developed a technology that is able to adopt processes and human thinking that technology Artificial Intelligence or Artificial Intelligence. The purpose of this study is to build a knowledge-based system of medicine in the diagnosis of eye diseases in the community that can be displayed in the computer, so the time efficiency reasons and lack of public awareness of health can be resolved. The use of methods grounded (grounded research) on the use of researchers based identification gejal eye diseases and symptoms that caused this study resulted in an application that can identify eye disease based on symptoms that arise as well as providing advice on the treatment and how to cope. Applications built using the PHP programming language and MySQL database. Application of expert system is capable of being a medium of information for the public on eye diseases with the help of technology optimally.
\end{abstract}

Keywords: expert system, eye diseases, php

Abstrak. Seiring perkembangan teknologi, dikembangkan pula suatu teknologi yang mampu mengadopsi proses dan cara berpikir manusia yaitu teknologi Artificial Intelligence atau Kecerdasan Buatan. Tujuan penelitian ini adalah untuk membangun sebuah sistem berbasis pengetahuan kedokteran dalam mendiagnosa penyakit mata pada masyarakat yang dapat ditampilkan dalam perangkat komputer, sehingga alasan efisiensi waktu dan kurangnya pengetahuan masyarakat akan kesehatan dapat teratasi. Penggunaan metode grounded (grounded research) di gunakan peneliti berdasarkan identifikasi penyakit mata dan gejal-gejala yang di timbulkan Penelitian ini menghasilkan sebuah aplikasi yang dapat mengidentifikasi penyakit mata berdasarkan gejala-gejala yang muncul serta memberikan saran pengobatan dan cara mengatasinya. Aplikasi dibangun menggunakan bahasa pemrograman PHP dan database MySQL. Aplikasi sistem pakar ini mampu menjadi media informasi bagi masyarakat untuk penyakit mata dengan bantuan teknologi secara optimal.

Kata Kunci : sistem pakar, penyakit mata, php

\section{PENDAHULUAN}

Seiring perkembangan teknologi, dikembangkan pula suatu teknologi yang mampu mengadopsi proses dan cara berpikir manusia yaitu teknologi Artificial Intelligence atau Kecerdasan Buatan. Sistem Pakar adalah salah satu bagian dari Kecerdasan Buatan yang mengandung pengetahuan dan pengalaman yang dimasukkan oleh satu atau banyak pakar ke dalam satu area pengetahuan tertentu sehingga setiap orang dapat menggunakannya untuk memecahkan berbagai masalah yang bersifat spesifik, dalam hal ini adalah permasalahan Penyakit mata.

Sistem pakar dapat diterapkan pada berbagai bidang kehidupan,termasuk juga dalam bidang kedokteran yaitu Diagnnosa penyakit Mata. Diagnosa merupakan perpaduan dari aktifitas intelektual dan manipulatif. Diagnosis sendiri didefinisikan sebagai suatu proses penting pemberian 
nama dan pengklasifikasian penyakit-penyakit pasien, yang menunjukkan kemungkinan nasib pasien dan yang mengarahkan pada pengobatan tertentu.

Penyakit mata sangat beragam dan tidak semuanya dapat menular. Jika penyakit mata disebabkan virus atau bakteri maka bisa menular, sedangkan jika penyebabnya alergi tidak akan menular. Cara penanganan dan pencegahan macam-macam penyakit mata ini pun berbeda, tergantung penyebabnya. Berikut ini beragam penyakit mata yang perlu Anda ketahui: agar tidak terjadi glaukoma karena kepekaan syaraf pada otot konjungtiva pada

Kecerdasan buatan menurut Rich dan Knight (1991:3) dapat didefinisikan sebagai suatu pengajaran, bagaimana manusia menjadikan komputer melakukan sesuatu yang oleh manusia saat itu dapat dilaksanakan lebih baik.

\section{Sistem Pakar}

Sistem pakar merupakan sistem yang menunjukkan adanya solusi permasalahan layaknya seorang pakar. Sistem pakar adalah aplikasi berbasis komputer yang digunakan untuk menyelesaikan masalah sebagaimana yang dipikirkan oleh pakar. (Kusrini, 2006)

Dengan sistem pakar ini, orang awam pun dapat menyelesaikan masalahnya atau hanya sekedar mencari suatu informasi berkualitas yang sebenarnya hanya dapat diperoleh dengan bantuan para ahli di bidangnya. Sistem pakar ini juga akan dapat membantu aktivitas para pakar sebagai asisten yang berpengalaman dan mempunyai asisten yang berpengalaman dan mempunyai pengetahuan yang dibutuhkan. Dalam penyusunannya, sistem pakar mengkombinasikan kaidahkaidah penarikan kesimpulan (inference rules) dengan basis pengetahuan tertentu yang diberikan oleh satu atau lebih pakar dalam bidang tertentu. Kombinasi dari kedua hal tersebut disimpan dalam komputer, yang selanjutnya digunakan dalam proses pengambilan keputusan untuk penyelesaian masalah tertentu.

\section{Penyakit Mata}

Mata merupakan alat indra yang terdapat pada manusia. Secara konstan mata menyesuaikan jumlah cahaya yang masuk, memusatkan perhatian pada objek yang dekat dan jauh serta menghasilkan gambaran yang kontinu yang dengan segera dihantarkan ke otak.

Data penyakit mata dan gejalanya (Riorda-Eva, 2010) sebagai berikut :

Tabel 1.Data Tabel Penyakit Mata

\begin{tabular}{ll}
\hline No & Nama Penyakit Mata \\
\hline 1 & Ulkus Kornea \\
2 & Konjungtivitis Vernalis \\
3 & Keratitis Pungtata Suferisialis \\
4 & Konjungtivitis \\
5 & Episkleris \\
6 & Skleris \\
7 & Alergi Mata Merah \\
8 & Hordeolum
\end{tabular}

\section{METODE}

Metode penelitian yang digunakan penulis adalah metode grounded (grounded research) yaitu suatu metode penelitian berdasarkan pada fakta dan menggunakan analisis perbandingan dengan tujuan mengadakan generalisasi empiris, menetapkan konsep, membuktikan teori, mengembangkan teori, pengumpulan dan analisis data dalam waktu yang bersamaan. Dalam riset ini data merupakan sumber teori atau teori berdasarkan data. 
Penulis bukan hanya mencari dan mengumpulkan data, tetapi juga langsung melakukan klasifikasi terhadap data tersebut, mengolah dan menganalisa data, membangun hipotesis menjadi teori serta menulis draft kasar laporannya dari waktu ke waktu.

Langkah-langkah pokok yang digunakan pada metode ini yaitu menentukan masalah yang ingin diselidiki, mengumpulkan data atau informasi yang ada dilapangan, menganalisis dan menjelaskan masalah yang ditemukan serta mebuat lapora hasil penelitian.

\section{Forward Chaining}

Menurut Giarratano dan Riley, forward chaining adalah salah satu metode dari sistem pakar yang mencari atau menelusuri solusi melalui masalah. Dengan kata lain metode ini melakukan pertimbangan dari fakta-fakta yang kemudian berujung pada sebuah kesimpulan yang berdasarkan pada fakta-fakta. Metode ini merupakan kebalikan dari metode backward chaining yang melakukan pencarian yang berawal dari hipotesis menuju ke fakta-fakta untuk mendukung hipotesis tersebut. Pada metode forward chaining, penjelasan tidak terlalu terlalu terfasilitasi karena subgoals tidak diketahui secara eksplisit sebelum kesimpulannya ditemukan. Forward chaining disebut juga bottom-up reasoning atau pertimbangan dari bawah ke atas, karena metode ini mempertimbangkan dari bukti-bukti pada level bawah, faktafakta, menuju ke kesimpulan pada level atas yang berdasarkan pada fakta-fakta.

\section{Bahasa Pemrograman HyperText PreProcessor (PHP)}

Nugroho (2008:113) PHP ( Hypertext Preeprocesor ) merupakan bahasa yang hanya dapat berjalan pada server dan hasilnya di tampilkan pada Client.

Konsep PHP sangat sederhana, bahkan lebih sederhana dari CGI. Sehigga dalam membuat dokumen PHP, cukup membuat sebuah HTML biasa, hanya saja ditambahkan dengan kode-kode program yang diapit dalam tanda $\langle ? \ldots \ldots . . . ?\rangle$. dalam hal ini Interpreter PHP dalam mengeksekusi kode PHP ini berjalan pada sisi server (disebut server-side), sehingga sangat berbeda sekali dengan program maya java yang mengeksekusi program pada sisi client (client-side). Proses eksekusi kode PHP disisipkan pada halaman HTML secara diagram

\section{Database MySQL}

Prasetyo (2002:1) menyatakan bahwa MySQL merupakan sebuah perangkat lunak sistem manajemen basis data atau DBMS yang multiuser, dengan sekitar 6 juta instalasi diseluruh dunia. Karena sifatnya yang open source dan memiliki kemampuan menampung kapasitas yang sangat besar, maka MySQL menjadi database yang sangat popular dikalangan programmer web. MySQL dapat dijalankan dalam 2 Operating system yang sangat popular saat ini, yaitu Windows dan Linux. MySQL merupakan perangkat lunak gratis dibawah lisensi GPL (General Public Lixense). Di mana setiap orang bebas untuk menggunakan MySQL.

\section{HASIL DAN PEMBAHASAN}

\section{Representasi Pengetahuan Pakar kedalam Sistem pakar}

Pengetahuan yang diperoleh dari pakar direpresentasikan kedalam bentuk tabel keputusan Tabel keputusan yang dirancang dapat dilihat dibawah ini : 


\begin{tabular}{|c|c|c|c|c|c|c|c|}
\hline & 1 & 2 & 3 & 4 & $=$ & 0 & 7 \\
\hline 1. Terdagat darah di bilik mata & & & $\sqrt{ }$ & & & & \\
\hline 2. Bulu masta rontok & & & & $\sqrt{ }$ & & & \\
\hline 3. Melihat Kilatan-kilatan bintilk & & & & & $\sqrt{v}$ & & \\
\hline $\begin{array}{l}\text { 4. Terdigat bercalk gelap di lapangan } \\
\text { pandangan }\end{array}$ & & & & & & 7 & \\
\hline 5. Bulu mata melenghung ke dalsm & & & & & & & \\
\hline 6. Sakit keppla di dgrah tenghulk & $\sqrt{ }$ & & & & & & \\
\hline 7. radeng pada mata & & & & & & & \\
\hline 8. Mata berair & $\sqrt{ }$ & & $\sqrt{ }$ & $\sqrt{ }$ & & & $\sqrt{ }$ \\
\hline 9. Cepat ngantulk & $\sqrt{ }$ & & & & & & \\
\hline 10. mata terasa padas & $\sqrt{ }$ & & & & & & \\
\hline 11. Renglingtan kabur & $\sqrt{ }$ & & & & & & \\
\hline 12. Ragal pada bola mats & & & & & & & \\
\hline 13. Keluar air mat berlebih & & $\sqrt{ }$ & $\sqrt{ }$ & & & & \\
\hline 14. Penurunan penglihatan & & $\sqrt{ }$ & & & $\sqrt{ }$ & & \\
\hline 15. Mats merah & & $\sqrt{2}$ & & $\sqrt{ }$ & & 4 & $\sqrt{ }$ \\
\hline 16. Sensitif terhadap cahaya & & $\sqrt{ }$ & & $\checkmark$ & & 7 & $\sqrt{ }$ \\
\hline 17. Belelkan & & & & $\sqrt{ }$ & & & $\sqrt{ }$ \\
\hline 18. Mats terasa kering & & & & $\sqrt{ }$ & & & \\
\hline 19. Pandangan Kabur & & & & & & $\sqrt{ }$ & \\
\hline 20. Kelopalk mata bengkal: & & $\sqrt{ }$ & & & & & \\
\hline 21. Mata benglkak: & & & & & & & $\sqrt{ }$ \\
\hline
\end{tabular}

Tabel 1. Tabel keputusan

\section{Penjelasan tabel}

P001 :Refraksi, P002 :Keratitis , P003 : Hefinia, P004 :Blefaritis, P005 :Ablan Retina ,P006 :

Uveitis, P007 :Traukoma

Perlu kita ketahui bahwa representasi pengetahuan ini nantinya akan digunakan untuk menentukan kesimpulan yang didapat .Berdasarkan pada tabel 1

1) Aturan 1 atau rule 1

Kita dapat menentukan aturan yang digunakan untuk penyakit Refraksi, yaitu :

Jika Sakit kepala di daerah tengkuk

Dan Mata berair, Dan Cepat mengantuk, Dan Mata terasa pedas, Dan Pegal pada

bola mata, Dan Penglihatan kabur

\section{Maka Kelainan Refraksi}

\section{2) Aturan 2 atau rule 2}

Kita dapat menentukan aturan yang digunakan untuk penyakit Keratitis, yaitu :

Jika Keluar air mata yang berlebihan

Dan Nyeri mata, Dan Penurunan penglihatan, Dan Mata merah, Dan Radang pada

kelopak mata, Dan Sensitif terhadap cahaya

\section{Maka Keratitis}

\section{3) Aturan 3 atau rule 3}

Kita dapat menentukan aturan yang digunakan untuk penyakit Hifenia, yaitu :

Jika Terdapat darah di daerah bilik mata

Dan Mata berair, Dan Muntah, Dan Penglihatan menurun

Maka Hefina

4) Aturan 4 atau rule 4

Kita dapat menentukan aturan yang digunakan untuk penyakit Blefaritis, yaitu : 
Jika Iritasi matsa

Dan Keluar air mata yang berlebihan, Dan Adanya benda asing, Dan Belekan

Dan Mata teras kering, Dan Mata merah, Dan Kelopak mata gatal, Dan Sensitif terhadap cahaya, Dan bulu mata rontok

Maka Blefaritis

5) Aturan 5 atau rule 5 Kita dapat menentukan aturan yang digunakan untuk penyakit Ablasi retina, yaitu : Jika Melihat kilatan-kilatan cahaya bintik hitam Dan Adanya tirai yang menutup sebagian lapangan mata, Dan Kemunduran penglihatan Maka Ablasi retina

6) Aturan 6 atau rule 6 Kita dapat menentukan aturan yang digunakan untuk penyakit Uvetis, yaitu : Jika Mata merah Dan Mata Nyeri, Dan Sensitif terhadap cahaya, Dan Pandangan kabur dan kurang jelas, Dan terdapat bercak gelap di lapangan pandangan Maka Uveitis

7) Aturan 7 atau rule 7Kita dapat menentukan aturan yang digunakan untuk penyakit Trakoma ,yaitu : Jika Mata gatal dan kemerahan Dan Mata berair, Dan Mengeluarkan kotoran mata berwarna keruh, Dan Takut terhadap cahaya, Dan Kelopak mata bengkak, Dan Bilu mata melengkung ke dalam Maka Trakoma

\section{Algoritma Penyelesaian Masalah dengan Flowchart dan Pseudocode}

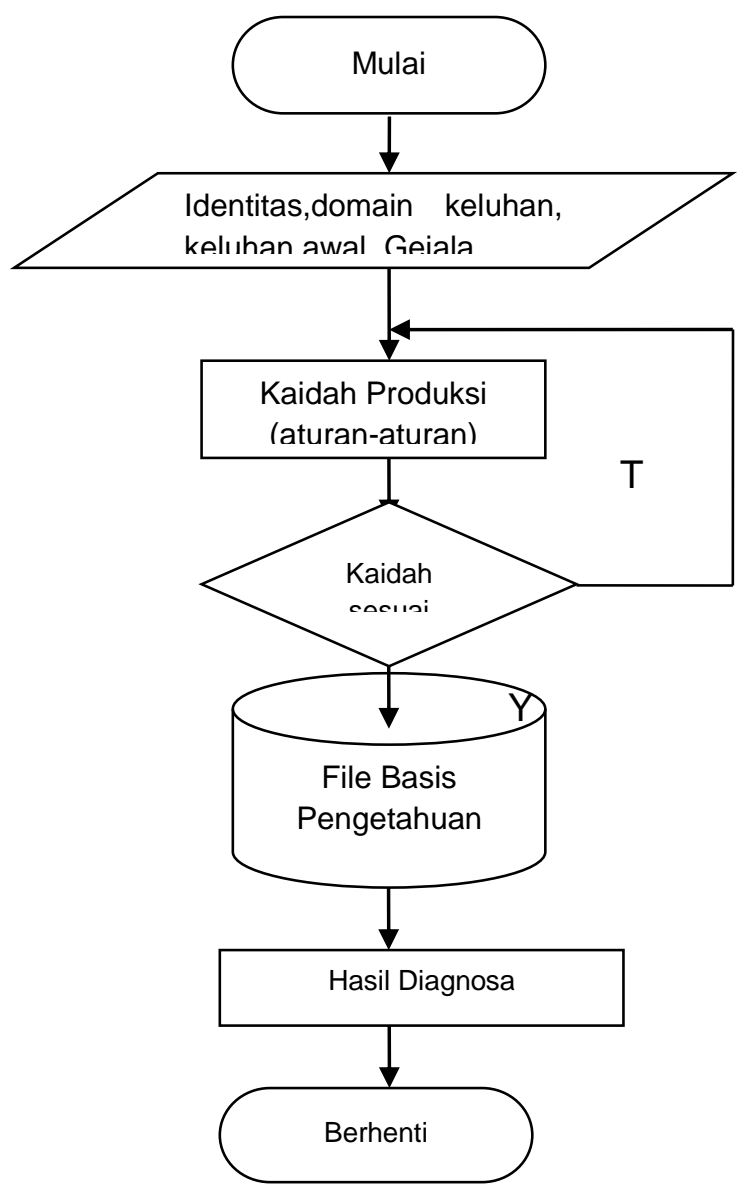

Gambar 2. Algoritma Penyelesaian masalah 
Flowchart dan Pseudocode

Flowcart sistem pakar Diagnosa penyakit mata adalah sebagai berikut :

Flowcard user

Tampilan Menu Awal

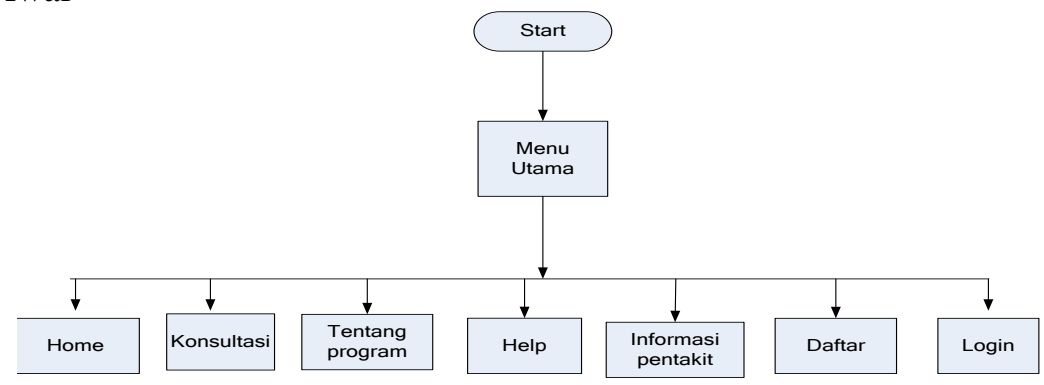

Pseudocode:

Gambar 3 Flowchart Menu Utama

Tampilkan menu awal

Pilih="Tampilan Awal" masukkan modul menu pada Tampilan Awal

Do pilihan

Pilih="Home" lakukan modul menu Home

Pilih="Konsultasi" lakukan modul menuKonsultasi

Pilih="Tentang Program" lakukan modul menu Tentang Program

Pilih="Help" lakukan modul menu Help

Pilih="Informasi Penyakit" lakukan modul menu Informasi Penyakit

Pilih="Daftar lakukan modul menu Daftar

Pilih= "Login" lakukan modul menu Login

End pilihan

1) Tampilan Konsultasi

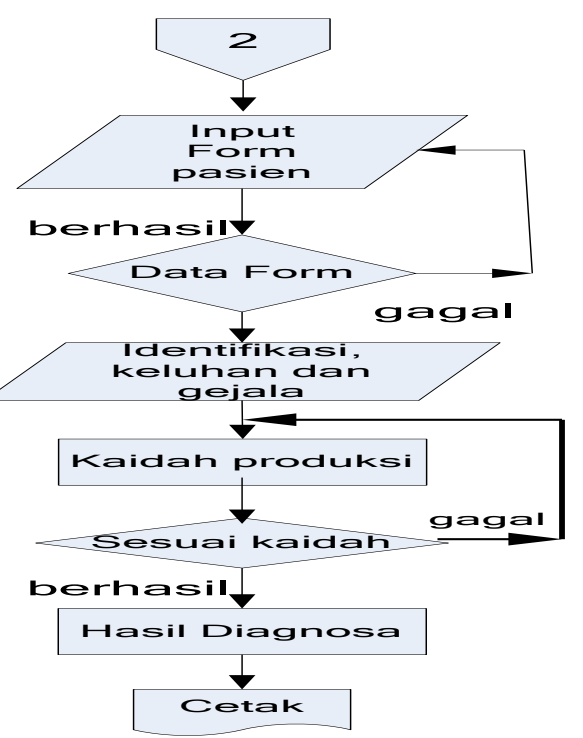

Gambar 4 Flowchart Konsultasi 
Faktor Exacta 11 (1): 47-56, 2018

p-ISSN: 1979-276X

e- ISSN: 2502-339X

Pseudocode:

Tampilkan Menu Input Form Pasien

Pilh="Input Form Pasien" Tampilkan Input Form Pasien

If jawab= "Berhasil" then

Tampilkan Menu Data Form

Else

Kembali ke Menu Input Form Pasien

Pilih= "Identifikasi, Keluhan dan Gejala" Tampilkan Menu Identifikasi, Keluhan dan Gejala

End if

If jawab = "Berhasil" then then Tampilkan menu hasil diagnosa

Else

Kembali ke menu Identifikasi, Keluhan dan Gejala

End if

End if

\section{Flowchart Admin}

Pseudocode:

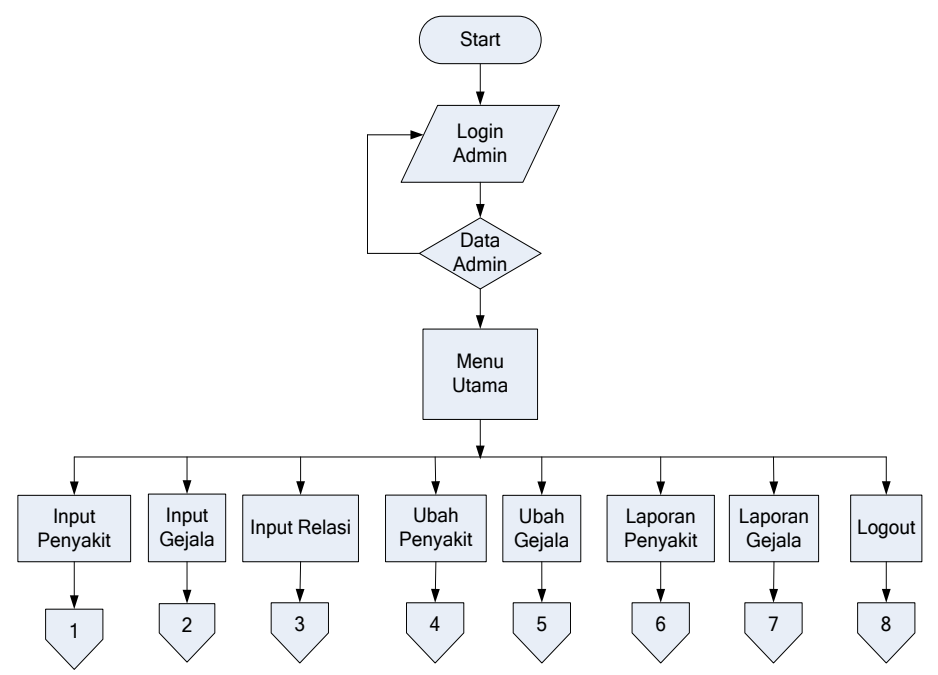

Gambar 5 Flowchart Admin

Tampilkan Login Admin

Pilh= "Inputlogin" Tampilkan Menu Utama

If jawab= "Berhasil" then

Tampilkan Menu Utama

Else

Kembali ke Login Admin

Do pilihan

Pilih="Home" Lakukan modul menu Home

Pilih = "Input Penyakit" Lakukan modul menu Input Penyakit

Pilih=" Input Gejala" Lakukan modul Input Gejala

Pilih="Ubah Penyakit" Lakukan modul menu Ubah Penyakit

Pilih="Ubah Gejala" Lakukan modul menu Ubah Gejala

Pilih="Laporan Penyakit" Lakukan modul menu Laporan Penyakit 
Pilih="Laporan Gejala" Lakukan modul menu Laporan Gejala

Pilih="'Logout" Lakukan modul menu Laporan Logout

Pilih="Login" Lakukan modul menu Login

End if

\section{Implementasi Sistem}

Implementasi sistem menggunakan bahasa pemrograman PHP dan database mySQL. Adapun tampilan pada sistem pakar penyakit mata:

Pada layar halaman utama ini terdapat beberapa jenis penyakit mata dan menampilkan beberapa menu pilihan utama yaitu :Home, Konsultasi, Tentang Program, Help, Informasi Penyakit, Daftar, Login

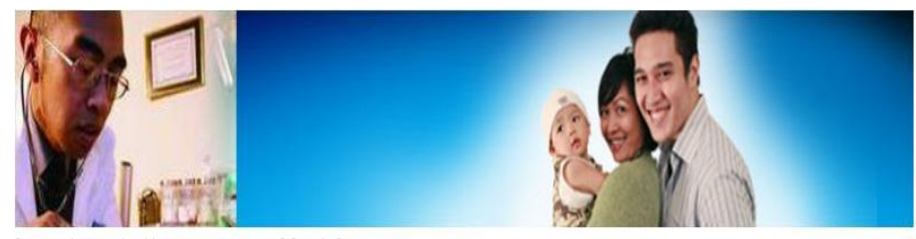

\section{[ Home $|\underline{\text { Konsultasi }}| \underline{\text { Tentang Program }] \text { [ Help ] }}$}

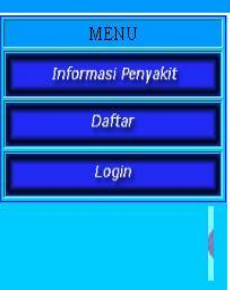

Anda belum login :

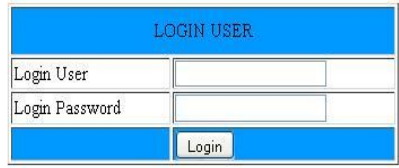

Gambar 6.Tampilan Menu utama

\section{Tampilan layar Konsultasi}

Tampilan Layar Menu Diagnosa menampilkan option- option pilihan domain masalah mengenai penyakit mata.

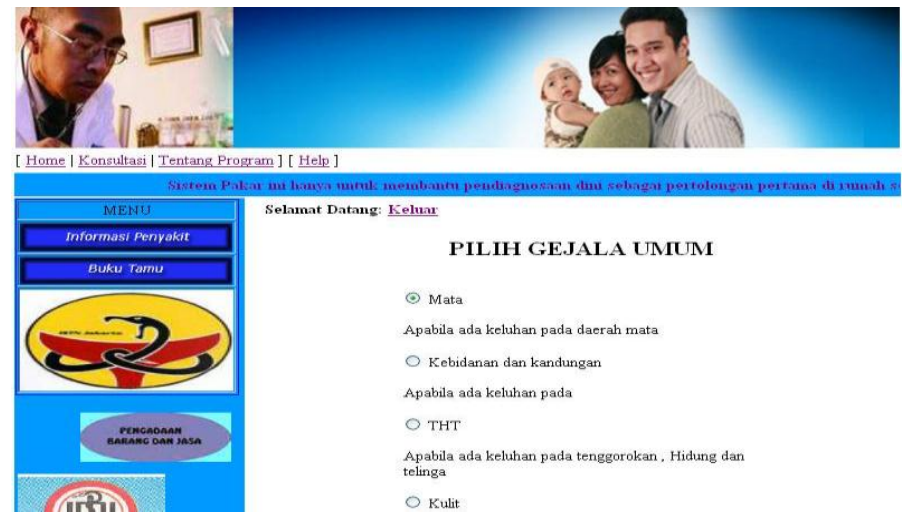

Gambar 7 Tampilan Layar Menu Konsultasi

Tampilan Layar konsultasi user

Tampilan Layar Menu konsultasi user menampilkan pertanyaaan mengenai gejala-gejala yang dirasakan oleh user. 


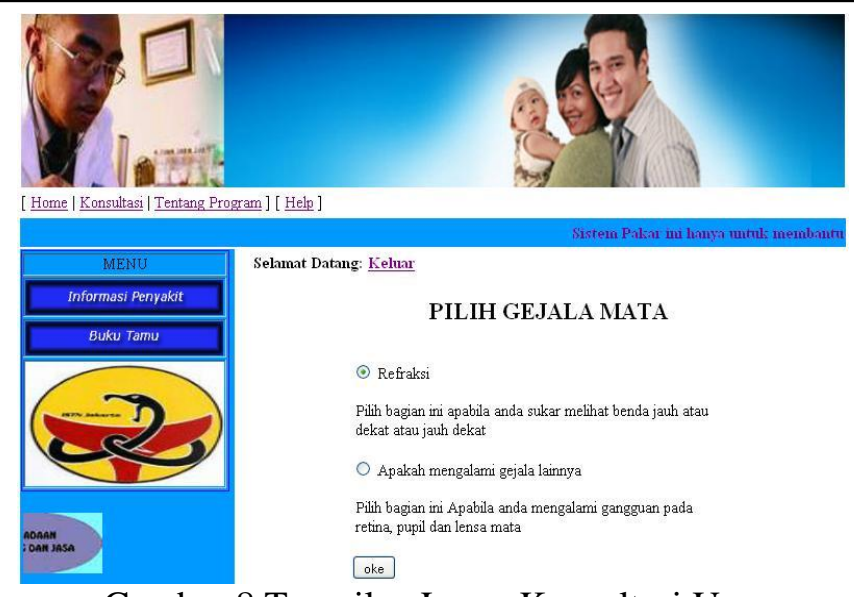

Tampilan Layar Menu Informasi Penyakit

Gambar 8 Tampilan Layar Konsultasi User

Pada tampilan ini user mendapatkan informasi mengenai definisi, gejala dan Pengobatan berbagai macam penyakit.

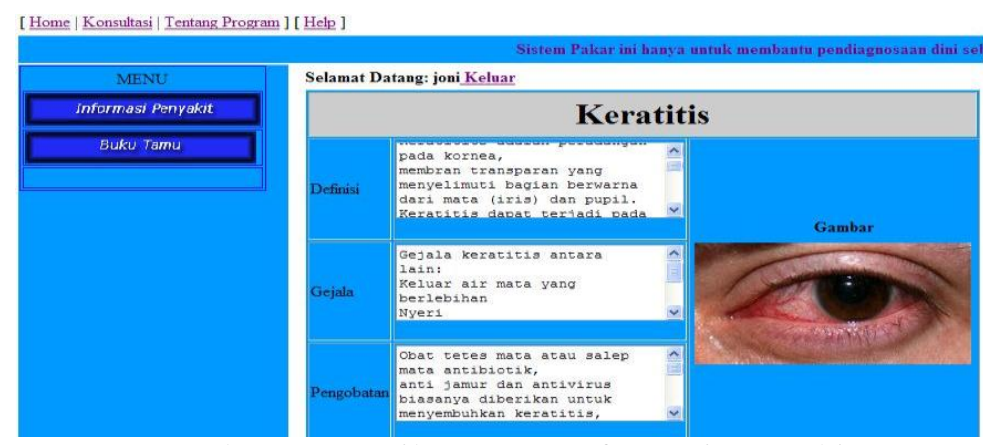

\section{PENUTUP}

Gambar 9 Tampilan Layar Informasi Penyakit

\section{Simpulan}

Berdasarkan hasil analisa, perancangan serta evaluasi sistem, dapat ditarik kesimpulan bahwa :

1. Sistem pakar Teknologi diagnosa untuk penyakit umum dan penanggulangannya merupakan prototipe sistem pakar yang memanfaatkan teknologi komputer yang dirancang dengan tujuan untuk membantu pendiagnosaan dini dalam bidang kesehatan masyarakat.

2. Prototipe Sistem Pakar untuk mendiagnosa penyakit mata ini tidak dapat menjadi pengganti ahli medis tetapi hanya sebagai sarana alat Bantu medis yang dapat direkomendasikan sebagai usulan media, selain brosur-brosur, buku dan majalah.

\section{Saran}

Sebuah sistem yang dirancang tidak pernah akan sempurna karena sistem akan terus berkembang. Berdasarkan hal tersebut, maka terdapat beberapa saran yang harus dipertimbangkan, saran-saran tersebut adalah sebagai berikut :

1. Penerapan Sistem Pakar berbasiskan internet sebaiknya dilakukan untuk pengembangan sistem pakar selanjutnya, agar dapat lebih bermanfaat digunakan oleh banyak orang.

2. Agar dapat digunakan secara maksimal dan menjadi suatu alat bantu yang handal, sebaiknya domain permasalahan ditambah tidak hanya seputar penyakit umum, tetapi mungkin lebih khusus.

3. Sistem yang dirancang sebaiknya dibuat dengan multimedia agar lebih interaktif, menarik dan user friendly.

\section{DAFTAR PUSTAKA}


Dwi Prasetyo Didik. Administrasi Database Server MySq1. Penerbit Elex Media Komputindo. 2002.

Elaine Rich and Kevin Knight, Artificial Intelligence, Second Editions, 1991.

Giarratano, J. C. dan Riley, G. D. Expert Systems Principles and Programming Fourth Edition, 167173. Boston, Massachusetts: Thomson Course Technology. 2005.

Kusrini. Sistem Pakar Teori dan Aplikasi. Penerbit :Andi, Yogyakarta,2006

Nugroho Bunafit. Membuat Aplikasi Sistem Pakar Dengan PHP dan Editor Dreamever.

Penerbit GAVA MEDIA. 2008.

Munir Rinaldi. Algoritma dan Pemograman.Penerbit Informatika, 2002.

Janner Simarmata dan Imam Prayudi. Basis Data. Penerbit ANDI, 2005.

Riordan-Eva $\mathrm{P},$. .Anatomi \& Embriologi Mata In :Vuughan Asbury. Oftalmologi Umum Edisi 17.Jakarta:EGC .2010 